\title{
What are the factors of tax evasion? New findings in the EVS Study
}

\section{Tereza Ryšavá, Hana Zídková ${ }^{1}$}

\begin{abstract}
This paper is analyzing tax morale in three selected European countries through the evaluation of the results of the European Values Study. The main aim is to identify the factors that influence taxpayers' decisions on the issue of whether they justify cheating on tax or not. The dependence and effect of selected factors were determined by analyzing data from the latest European Values Study (2019). The analysis revealed that not only demographic factors (gender, a ge), but also other socio-economic and institutional factors (religion, willingness to defend the home country, being a proud citizen, trust in government and respect for authorities) have a significant impact on taxpayers' justification of cheating on taxes. This research is specifically focused on the Czech Republic, Poland and Spain.
\end{abstract}

Keywords: European Values Study, chi-square test, tax avoidance, tax compliance, tax morale.

JEL Classification: H26, H31, K34.

Received: 21 March 2021/Accepted: 24 September 2021/Sent for Publication: 13 December 2021

\section{Introduction}

Tax eva sion has a significant impact on tax revenues in most countries of the world. Most states have been fighting tax evasion for a long time, making legislative changes and implementing tools to reduce the possibility of committing tax fraud and speeding up its detection. However, tax evasion must be viewed not only from a legal point of view, which in many cases is an illegal activity, but also from the moralside of such behavior. Nowadays, we can usually encounter the optimization of the tax base, which is carried out in accordance with the legislation of the country, or the targeted use of loopholes in the law. From a legal point of view, such conduct may be completely legal, but from a social point of view, it is immoral.

Tax morale is generally defined as " the intrinsic motivation to pay taxes" or "the willingness to pay taxes" (Torgler, 2007). The issue of motives for tax evasion and tax morale has been examined in recent years in a number of empirical studies. Researchers look at

\footnotetext{
${ }^{1}$ Prague University of Economics and Business, the Czech Republic, terkarysava11@gmail.com, hana.zidkova@vse.cz (corresponding author), ORCID Identifier [0000-0003-3661-6993]. 
the understanding of what motivates taxpayers to participate in the tax system and to comply with tax law.

A better understanding of taxpayers' behavior, motives and attitudes towards taxation can contribute both to increased voluntary compliance and more efficient tax administration (Walsh, 2012). Increasing tax compliance means higher tax revenues for tax administrations and for taxpayers better tax systems that suit their needs. In all countries, tax revenues are the main source of financing public services, which is why it is so important for all countries to understand the behavior of tax subjects. Examining tax morale thus provides a way to a chieve voluntary compliance with tax regulations and at the same time, it can be used as a tool to explain differences in the efficiency of tax systems (OECD, 2019).

The aim of this article is to find out how not only demographic but also socio-economic and institutional factors relate to tax morale in three European countries, Poland, Spain and the Czech Republic. The analysis's ma in contribution is the use of the latest da from the European Values Study (2019). Moreover, new factors that have not yet been specifically analyzed in the previous litera ture using the EVS data will be examined. We believe that a comparison of the three above mentioned countries with different levels of tax morale declared by the respondents in the survey could reveal interesting differences in attitudes of those countries' citizens.

The first part of the article summarizes the literature dealing with the factors of tax evasion, then the second part describes the data used and explains the statisticalmethod used to determine the relationship between selected factors and tax morale. Finally, the results of the analysis will be discussed, and conclusions drawn. For greater clarity of the text, detailed results of statistical tests for individual factors and countries are given in the appendix.

\section{Overview of literature}

Tax compliance is affected by a number of different a spects. In the report from the Forum of Tax Administration, the OECD (2010) divides the factors influencing tax evasion into five main groups (which are interconnected):

- Deterrence - such as the probability of a tax audit, the risk of detection of tax evasion during the audit, the severity of punishment or penalties in the case of tax evasion.

- Personal and social norms.

- Opportunities

$\circ$ for compliance (minimizing costs related to the fulfillment of tax obligations, clarity of tax law, complexity of the tax system, simplifying forms).

○ for non-compliance (risk a version and social norms of the taxpayer, his perception of benefits from publicly provided services, the way of tax payment (e.g. withholding taxes are less prone to tax evasion), efficiency of tax administration in discovering tax evasion).

- Fairness of the revenue body or government.

- Economic factors - general economic factors, specific factors of the business or industry and the tax burden of economic subjects. 
Researchers looking for an explanation for tax evasion deal in one way or another with the above-mentioned areas as we describe below.

One of the first and well-known attempts to expla in the taxpayer's decision to cheat on taxes was accomplished by Allingham and Sandmo (1972), applying the neoclassical model of the maximum utility on criminal activity. They maximized the utility function of a risk-averse taxpayer given the probability of tax audit and the size of the penalty. Their model was extended by Yitzhaki (1974), adjusting the calculation of the penalty. It was further improved by using the growth model and making it dynamic by Dalamagas (2011).

The a mount of tax burden is important in assessing the risk of tax evasion and the potential benefit of the non-payment of tax. Agha and Haughton (1996) or Christie and Holzner (2006) for example found that higher VAT rates correlated with higher tax evasion in VAT.

Numerous other researchers added psychological factors to their studies (Kirchler, 2007, Kirchler, 2019 or Muehlbacher et al., 2011) and interactions between the taxpayers and society or state (Leroy, 2008, 2011). Hofmannet al. (2008) or Alm et al. (2019) concluded that external variables that affect the economic position of the taxpayer, as for example tax rates or detection probabilities, play a crucial role in tax compliance, but personal attitudes and motivations, as well as social norms, are of similar significance.

According to research by Hanousek and Palda (2002), who worked with data from the Czech Republic, Slovakia, Poland and Hungary, there is a positive correlation between tax evasion and government-provided public services. The survey showed that the lower the quality of government services, the more likely it is that the taxpayerwill avoid tax. Hordonic (2018) came to the same conclusion, i.e. finding a positive influence of the perception of the quality of public administration on tax morale. Other authors also confirm that higher trust in government or the judicial system improves tax morale (Torgler, 2012, Filer et al., 2019, Daude et al., 2012, Ledyard, 1995). Similar findings were presented by Dell'Anno (2009), who used a utility function that incorporates morale, fairness and the relationship between taxpayers and government.

Daude et al., 2012 also found that people who support democracy have higher tax morale than those who would rather vote for a different system of government. In the context of democracy, it has been shown that those who consider fiscal redistribution to be right, $i$. e. that the government should tax the rich and subsidize the poor, have higher tax morale than those who disagree with this approach. Konrad and Quari (2011) focused on patriotism and its influence on tax evasion, and they found that more patriotic people are less tolerant of tax evasion.

Furthermore, some researchers have shown that married or religious people have significantly higher tax morale than single or non-religious ones (Torgler, 2012). The higher tax mora le of religious people has also been proved in studies by Daude et al. (2012), Gutiérrez a Melguizo (2012) Muehlbacher et al. (2011) a Devos (2008).

Daude, Gutiérrez and Melguizo (2012) found that part-time or self-employed workers have lower tax morale than full-time employees. As a justification of these results, it is stated that full-time workers have less opportunity to cheat on taxes than the self-employed since the totalamount of the income tax is generally deducted by their employer. 
On the other hand, Kirchler et al. (2019) reported opposite results when analyzing the socalled mentalaccounting of the self-employed.

Other authors explored the demographic factors possibly important for the attitude to tax evasion. Torgler (2012) discovered that positive factors influencing tax compliance are age, marriage, religion and financial satisfaction, Chung and Trivedi (2003) confirmed that women are less prone to tax evasion than men. Hug and Sporri (2011) - based on the previous issues of the European and World Values Survey data (EVS and WVS, respectively) - support the conclusion that retired elderly married women are those with the highest tax morale. Age and female status as tax compliance fostering factors are also emphasized by Gaviria (2008). Zídková et al. (2018) confirmed the influence of age and the fact that women are more willing to comply with taxes.

Agent-based models added dynamics to the previous models considering the interactions between taxpayers, tax authorities, lawmakers and tax practitioners (Bloomquist, 2011). Interesting results were presented by Bicchieri and Xiao (2009) who found out that for the taxpayers' decision to evade taxes, it is more important what other taxpayers do than what they should do according to tax law. Alm (2012) points out that the trust between tax authorities and taxpayers leads to better tax compliance than enforcement. It is also well known from psychology that people react differently to potential gains than losses. In an experiment, Bazart and Pickhart (2011) found higher tax compliance when honest taxpayers could win money in a lottery.

The latest OECD study from 2019, dealing with the issue of tax evasion, is in line with the above-mentioned conclusions. The study evaluates data from the World Values Survey (2010-2014) and identifies the influence of the following demographic, institutional and socio-economic factors:

- Educational Attainment: More educated individuals have a more positive approach to paying taxes.

- Female: Women have higher tax morale than men.

- Age: Older people justify cheating on taxes less than younger people.

- Citizen: Citizens of the country have higher tax morale than non-citizens.

- Religious: Those who claim a faith or religious identity have a more positive approach to paying taxes.

- Meritocracy: Those who believe they are living in a meritocratic society have higher tax morale.

- Trust in Government: Individuals who trust their national government show higher tax morale than those who do not.

- $\quad$ Redistributive Democracies: People who consider fiscal redistribution as essential display higher tax morale.

- Support for Democracy: Individuals who consider democracy to be the best system of government in their country are less likely to justify cheating on taxes.

It is clear that not only demographic characteristics and social norms of the respondents but also their perception of the government policy, performance and the ability of government to respond to the needs of citizens have a significant impact on tax morale. 


\section{Data and methodology}

\section{Data}

To determine the relationship between tax morale and certain demographic, socio-economic and institutional factors, we used data from the European Values Study database (EVS, 2019). The European Values Study (EVS) is a large-scale, transnational and longterm project focused on research into funda mental human values. These projects examine the preferences, attitudes, values, opinions and beliefs of citizens across the whole Europe. The main topics of the surveys are life, family, work, religion, politics and society.

The EVS surveys focus on a wide range of values and comparable questions that were given to respondents. By random sampling, more than 56,000 people from 30 European countries were interviewed. The following analysis is based on data from the latest a vailable survey published in 2019 (data were collected in 2017), specifically focusing on the question of respondents' tax morale. "Please tell me for the following statement whether you think it can always be justified, never be justified, or something in between: Cheating on tax if you have the chance?". Respondents decided on a ten-point scale where $1=$ never and $10=$ always.

For the purposes of this a nalysis, the original ten-point scale was modified to a five-point scale as below:

Table 1. Modified point scale

\begin{tabular}{lc} 
Original point scale & Modified point scale \\
\hline 1 (Never) & Never \\
$2,3,4$ & Rathernot \\
5,6 & Do not know \\
$7,8,9$ & Ratheryes \\
10 (Always) & Always \\
\hline
\end{tabular}

Source: Authors' modification based on data from the European Values Study

The reason for the unification was mainly the fact that at some levels of the ten -point scale, the answers were rare and the input data would not be usable for the analysis due to low or zero frequencies. Furthermore, the unification of data was also suitable for increasing the clarity of the graphs used. The most common answer of the respondents was that cheating on tax can never be justified. Table 2 shows the results of justifying cheating on tax for each participating country from the EVS study (2019). Based on this research, cheating on tax is the least justified in Albania, where almost $85 \%$ of respondents said they would neverjustify it. Around $80 \%$ of respondents who would never justify cheating on tax were also in Hungary, Poland and Bulgaria. On the contrary, the most tolerant respondents to cheating on tax are in Russia, Armenia and Azerbaijan. Spain and Romania are also among the countries where citizens are more tolerant of tax evasion. The Czech Republic ranked in the middle with $65 \%$. 
Table 2. The level of justification for cheating on tax in each country

\begin{tabular}{|c|c|c|c|c|c|}
\hline Country & Never & Rather not & Do not know & Rather yes & Always \\
\hline Russia & $32.70 \%$ & $21.80 \%$ & $33.00 \%$ & $6.50 \%$ & $6.10 \%$ \\
\hline Belarus & $37.10 \%$ & $26.40 \%$ & $29.40 \%$ & $5.00 \%$ & $2.00 \%$ \\
\hline Armenia & $37.40 \%$ & $20.70 \%$ & $25.60 \%$ & $8.80 \%$ & $7.50 \%$ \\
\hline Slovakia & $45.40 \%$ & $30.50 \%$ & $20.60 \%$ & $2.10 \%$ & $1.30 \%$ \\
\hline Azerbaijan & $47.60 \%$ & $24.20 \%$ & $15.90 \%$ & $9.00 \%$ & $3.40 \%$ \\
\hline Lithuania & $47.90 \%$ & $22.50 \%$ & $25.60 \%$ & $2.50 \%$ & $1.30 \%$ \\
\hline Spain & $54.10 \%$ & $20.00 \%$ & $13.90 \%$ & $8.00 \%$ & $4.00 \%$ \\
\hline Netherlands & $57.10 \%$ & $27.20 \%$ & $13.50 \%$ & $1.50 \%$ & $0.60 \%$ \\
\hline Switzerland & $62.30 \%$ & $25.20 \%$ & $9.50 \%$ & $1.60 \%$ & $1.50 \%$ \\
\hline Iceland & $63.20 \%$ & $24.60 \%$ & $10.50 \%$ & $0.80 \%$ & $0.80 \%$ \\
\hline France & $63.60 \%$ & $22.60 \%$ & $11.00 \%$ & $1.50 \%$ & $1.20 \%$ \\
\hline Georgia & $64.10 \%$ & $15.20 \%$ & $15.60 \%$ & $2.50 \%$ & $2.50 \%$ \\
\hline Romania & $64.90 \%$ & $10.10 \%$ & $15.50 \%$ & $3.30 \%$ & $6.30 \%$ \\
\hline Czech Republic & $65.40 \%$ & $19.60 \%$ & $12.00 \%$ & $1.50 \%$ & $1.60 \%$ \\
\hline Italy & $65.90 \%$ & $17.90 \%$ & $13.80 \%$ & $1.10 \%$ & $1.30 \%$ \\
\hline Finland & $66.20 \%$ & $25.80 \%$ & $6.20 \%$ & $0.90 \%$ & $0.80 \%$ \\
\hline Austria & $68.90 \%$ & $19.60 \%$ & $9.60 \%$ & $1.50 \%$ & $0.50 \%$ \\
\hline Sweden & $69.10 \%$ & $24.00 \%$ & $5.60 \%$ & $1.00 \%$ & $0.40 \%$ \\
\hline Estonia & $69.20 \%$ & $15.30 \%$ & $13.20 \%$ & $1.20 \%$ & $1.10 \%$ \\
\hline Slovenia & $69.90 \%$ & $20.20 \%$ & $7.80 \%$ & $1.10 \%$ & $1.00 \%$ \\
\hline Norway & $71.00 \%$ & $21.10 \%$ & $6.00 \%$ & $1.00 \%$ & $0.90 \%$ \\
\hline Serbia & $71.90 \%$ & $12.20 \%$ & $12.60 \%$ & $1.80 \%$ & $1.50 \%$ \\
\hline Great Britain & $72.60 \%$ & $17.40 \%$ & $8.30 \%$ & $0.50 \%$ & $1.10 \%$ \\
\hline Croatia & $72.80 \%$ & $12.70 \%$ & $9.00 \%$ & $2.00 \%$ & $3.60 \%$ \\
\hline Germany & $73.40 \%$ & $18.60 \%$ & $6.50 \%$ & $0.80 \%$ & $0.80 \%$ \\
\hline Denmark & $74.80 \%$ & $19.30 \%$ & $4.80 \%$ & $0.60 \%$ & $0.60 \%$ \\
\hline Bulgaria & $79.00 \%$ & $10.00 \%$ & $9.00 \%$ & $0.70 \%$ & $1.20 \%$ \\
\hline Poland & $79.90 \%$ & $13.50 \%$ & $5.20 \%$ & $0.50 \%$ & $0.80 \%$ \\
\hline Hungary & $80.10 \%$ & $12.80 \%$ & $6.20 \%$ & $0.60 \%$ & $0.40 \%$ \\
\hline Albania & $84.60 \%$ & $5.80 \%$ & $6.80 \%$ & $1.50 \%$ & $1.30 \%$ \\
\hline
\end{tabular}

Source: Author's calculations based on data from the European Values Study 
The "tax morale" question is evaluated depending on the demographic and socio-economic factors chosen from the literature on tax evasion that are listed in Table 3.

Table 3. Factors tested for the dependence of tax morale on them

\begin{tabular}{cc} 
Number & Factors \\
\hline 1. & Gender \\
2. & Age \\
3. & Educational Attainment \\
4. & Religion \\
5. & Confidence in Government and Authorities \\
6. & Confidence in Other People in Society \\
7. & Willing to Fight for Own Country \\
8. & Proud Citizen \\
9. & Respect for Authority \\
\hline
\end{tabular}

Source: Authors' modification based on data from the European Values Study

We have deliberately selected several questions (questions 7 and 8) regarding patriotism, as this factor has not yet been investigated in the EVS data. We also emphasized questions about respect for authorities (question 9) and about trust in government (question 5). In our view, it is important to examine these very attitudes of citizens, because government policy can influence them to some extent.

We were also interested in respondents' answers about trust in other people (question 6), as some researchers (Bicchieri and Xiao, 2009) found that the impression that others did not pay taxes could lead to a tendency to avoid taxes. We also examined the socio-demographic characteristics of respondents such as gender and age (questions 1 and 2), as well as their education and religion (questions 3 and 4).

The following countries were selected to a nalyze the factors that may affect taxpayers' tax morale: the Czech Republic, Poland and Spain. The reason is that Poland and Spain represent two opposite extremes, with which the results of the Czech Republic are compared. Poland represents one of the European countries in which the population is the least willing to justify cheating on tax, and Spain, on the other hand, is one of the countries in which the population justifies it the most.

\section{Methodology}

The dependence of the answers to the "tax morale" question, i.e. the willingness to justify tax evasion, and selected factors was evaluated using the statistical chi-square test of independence. For this purpose, we used pivot tables with response rates to the "tax morale" question and each question representing the selected factor. The pivot tables contain conditional frequencies of answers to the evaluated question (factor) based on answering the "tax morale" question (see individual pivot tables in the appendix to this article).

We chose the chi-square test for the analysis of tax morale and the factors influencing it because it allows to verify hypotheses about the dependence between two variables in the pivot table. Our data from the EVS Study could be organized exactly in this format. Unfortunately, the strength of the dependence cannot be read from the chi-square test, nor 
can the countries be compared, because they have a different size of the samples (number of the respondents of the EVS Study).

Some papers mentioned in the review of literature dealing with this issue average the result of the answer to the question of whether respondents justify tax evasion and then use this avera ge value in the regression analysis as an independent variable and estimate the strength of the influence of individual factors as explanatory variables. However, in our opinion, a veraging the results is not correct and the use of regression analysis has its limits in this area since the variables do not have a normaldistribution, which is a condition for using the least squares method. Moreover, the results of regression models are often biased by omitted explanatory variables or endogeneity issues.

The independence chi-square test is based on a comparison of observed frequencies $n_{i j}$ to expected frequencies $n_{i}+n+j / n$. For the purposes of this analysis, the significance level was set at $\alpha=0.05$. To use this test, the input data have to meet the two following conditions:

not more than $20 \%$ of the theoretical frequencies may be less than 5 ,

none of the theoretical frequencies may be less than 1 .

The following hypotheses are tested:

H0: the variables are independent,

$\mathrm{H} 1$ : non $\mathrm{H} 0$, which means the variables are dependent,

based on the formula for $\mathrm{G}$

$$
G=\sum_{i=1}^{r} \sum_{j=1}^{s} \frac{\left(n_{i j}-n_{i+} n_{+j} / n\right)^{2}}{n_{i+} n_{+j} / n}
$$

which has a chi-square distribution with $\left.\left.G \approx \chi^{2}((r-1)(s-1))\right)\right)$ degrees of freedom, where $r$ is the number of rows and $s$ is the number of columns in the pivot table. The critical value has the form $W_{\alpha}=\left\{g ; g \geq \chi_{1-\alpha}^{2}\right\}$, where $g$ is the calculated value from the $\mathrm{G}$ formula. The calculated value from the $\mathrm{G}$ formula is compared with the critical value. If the calculated value is greater than (or equal to) the critical value, then we reject the hypothesis $\mathrm{H} 0$ at the $5 \%$ level of significance.

\section{Results and discussion}

The results of the analysis of the influence of selected factors on the justification of cheating on tax for the Czech Republic, Poland and Spain are shown in Table 4. An overview of the frequency of answers of the EVS respondents to the examined questions and the results of the performed tests of independence are included in the appendix to the article.

In the analysis of tax morale in Poland, in many cases the statistical test could not have been performed due to the low frequency of answers of those who would justify cheating on tax. If the direction of the effect of the given factor on the perception of tax evasion in Poland can be traced from the graphical representation of the answers, we have presented the graphs in the appendix so that the reader can get an idea . 
Table 4. The influence of analyzed factors on tax morale in the Czech Republic, Poland and Spain

\begin{tabular}{|c|c|c|c|}
\hline $\begin{array}{l}\text { Factor } I \\
\text { Country }\end{array}$ & Czech Republic & Poland & Spain \\
\hline Gender & $\begin{array}{l}\text { Dependence. } \\
\text { Women justify cheating } \\
\text { on tax less than men. }\end{array}$ & $\begin{array}{l}\text { Dependence. } \\
\text { Women justify cheating on } \\
\text { tax less than men. }\end{array}$ & $\frac{\text { Independence }}{\text { Influence notidentified. }}$ \\
\hline Age & $\begin{array}{l}\text { Dependence. } \\
\text { Tax morale increases } \\
\text { with age. }\end{array}$ & Test could not be performed. & $\begin{array}{l}\text { Independence. } \\
\text { Influence notidentified. }\end{array}$ \\
\hline $\begin{array}{l}\text { Educa- } \\
\text { tional At- } \\
\text { tainment }\end{array}$ & $\begin{array}{l}\text { Independence. } \\
\text { Influence notidentified. }\end{array}$ & $\begin{array}{l}\text { Independence. } \\
\text { Influence notidentified. }\end{array}$ & $\begin{array}{l}\text { Independence. } \\
\text { Influence notidentified. }\end{array}$ \\
\hline Religion & $\begin{array}{l}\text { Dependence. } \\
\text { Religious people have } \\
\text { higher tax morale. }\end{array}$ & Test could not be performed. & $\begin{array}{l}\text { Dependence. } \\
\text { Religious people have } \\
\text { higher tax morale. }\end{array}$ \\
\hline $\begin{array}{l}\text { Confi- } \\
\text { dence in } \\
\text { Govern- } \\
\text { ment and } \\
\text { Authori- } \\
\text { ties }\end{array}$ & $\begin{array}{l}\text { Dependence } \\
\text { Increasing confidence } \\
\text { has a positive impact on } \\
\text { tax morale. }\end{array}$ & Test could not be performed. & $\begin{array}{l}\text { Dependence } \\
\text { Increasing confidence has } \\
\text { a positive impact on tax } \\
\text { morale. }\end{array}$ \\
\hline $\begin{array}{l}\text { Confi- } \\
\text { dence in } \\
\text { Other Peo- } \\
\text { ple in So- } \\
\text { ciety }\end{array}$ & $\begin{array}{l}\text { Independence. } \\
\text { Influence notidentified. }\end{array}$ & $\begin{array}{l}\text { Independence. } \\
\text { Influence notidentified. }\end{array}$ & $\begin{array}{l}\text { Independence. } \\
\text { Influence notidentified. }\end{array}$ \\
\hline $\begin{array}{l}\text { Willing to } \\
\text { Fight for } \\
\text { Own } \\
\text { Country }\end{array}$ & $\begin{array}{l}\text { Dependence } \\
\text { Tax morale increases } \\
\text { with the willingness to } \\
\text { fight for own country. }\end{array}$ & $\begin{array}{l}\text { Dependence } \\
\text { Tax morale increases with } \\
\text { the willingness to fight for } \\
\text { own country. }\end{array}$ & $\begin{array}{l}\text { Dependence } \\
\text { Tax morale increases with } \\
\text { the willingness to fight for } \\
\text { own country. }\end{array}$ \\
\hline $\begin{array}{l}\text { Proud Citi- } \\
\text { zen }\end{array}$ & $\begin{array}{l}\text { Dependence. } \\
\text { Proud citizens have } \\
\text { higher tax morale. }\end{array}$ & Test could not be performed. & $\begin{array}{l}\text { Dependence. } \\
\text { Proud citizens have higher } \\
\text { tax morale. }\end{array}$ \\
\hline $\begin{array}{l}\text { Respect } \\
\text { for Au- } \\
\text { thority }\end{array}$ & $\begin{array}{l}\text { Dependence. } \\
\text { A positive perception of } \\
\text { increasing respect for au- } \\
\text { thorities increases tax } \\
\text { morale. }\end{array}$ & Test could not be performed. & $\begin{array}{l}\text { Dependence. } \\
\text { A positive perception of in- } \\
\text { creasing respect for author- } \\
\text { ities increases tax morale. }\end{array}$ \\
\hline
\end{tabular}

Source: Authors' calculations based on data from the European Values Study

Below, the links between selected factors and tax morale are described in more detail and the potentialcauses of these relationships are discussed, including a comparison of results for individual countries.

\section{Gender}

The first factor examined was gender. The results of our analysis showed a relationship between gender and the justification of tax evasion in the Czech Republic and Poland. In both countries, women are less likely to justify tax evasion than men, a result consistent with the findings of Torgler (2012), OECD (2019), Joshi, A. (2019) and other named 
authors. Our interpretation of these results is that they could potentially be caused by the psychological factors of women's lower willingness to take risks to the possibility and the fact that women are better aware of the benefits of public support, for example during maternity leave. In Spain, the test did not prove the dependence.

Age

Another factor on which the dependence of the justification of tax evasion was tested was age. As the previous research shows, with increasing age, the justification of tax evasion tends to decrease (eg Torgler, 2012, Gaviria, 2008, Zídková, 2018). The dependence of this factor was proved only in the Czech Republic, in Spain, the dependence was not proved. In the case of the Czech Republic, the cause of the correlation can, in our opinion, be found in the fact that older people are mostly pensioners who receive benefits from the social system, so they do not justify tax evasion. What causes the independence of justifying tax evasion on the factor of age in Spain and Poland is a question. We believe that this could be explained, for example, by intergenerational solidarity, where senior citizens are less dependent on pension income, which is paid from public budgets and thus from taxes.

\section{Educational Attainment}

The analysis of the third selected factor, which is the level of educational attainment, failed to prove dependence in any of the selected countries. Therefore, it cannot be stated from the results that the level of educational attainment would play an important role in deciding on the justification of tax evasion. This does not correspond to the conclusions of the previously mentioned authors that more educated people justify tax evasion less likely (e.g. Torgler, 2012, Daude, Gutiérrez and Melguizo, 2012). However, some authors mention the ambiguous effect of educational level on the willingness to cheat on taxes. For example, Zídková et al. (2018) found by analyzing older data from the EVS (2008) that the least educated respondents and also the most educated are the least willing to tolerate tax evasion. This may, in ouropinion, be related to the fact that the most educated people understand the tax system and its benefits, and the least educated have low incomes from which they do not pay high taxes and, conversely, can draw various benefits from public sources (e.g., during unemployment). However, our analysis did not reveal this pattern as the chi-quadrat test would show dependence between the attitude to tax evasion and the level of education even if it was non-linear.

\section{Religion}

In this part, respondents were a sked whether they are religious or not. The test proved the dependence of the (un)willingness to justify tax evasion on being religious. Although it was not possible to do the test in the case of Poland, the results show that in all three countries, religious people tend to tolerate tax evasion slightly less than non-religious people. This corresponds to the general assumption that a ll religions serve the same purpose in promoting good behavior and discoura ging bad behavior. Religion is expected to provide an internal control for self-monitoring and self-enforcement in moral behavior.

\section{Confidence in government and authorities}

In this part, it was tested whether the confidence of the population in the government and other authorities plays a role in deciding on the justification of tax evasion. Dependence 
was proved in the Czech Republic and Spain. It has been shown that the more people trust the state administration, the less willing they are to justify cheating on tax. It was not possible to perform the statistical test for Poland but based on a graphical analysis of the input data, a positive correlation can also be noted between growing confidence and refusing to justify tax evasion.

This finding confirms the results of research that was already carried out (Torgler, 2012, Filer et al., 2019, Daude et al., 2013, Ledyard, 1995, Dell'Anno, 2009), which shows that trust in government has a positive effect on tax morale. We agree with the mentioned authors that if the taxpayer perceives the quality of the public services provided as sufficient, it will rather give him the feeling that "his/her" money that he/she has paid to the state is being treated correctly and will be all the more willing to pay taxes.

\section{Confidence in other people in society}

In this case, people answered to what extent it is possible to trust people, or whether one must be very careful in dealing with other people. This factor was chosen based on the assumption that socialenvironment and norms can influence individuals' decisions (Hofmann et al., 2008). If we take into account the assumption that trust in other people is trust that other people pay taxes properly, it will probably mean that those who trust will be less willing to cheat on taxes. However, in this case the statistical test did not show dependence in any of the selected countries and the original assumption cannot be confirmed.

\section{Willing to fight for own country}

Another selected factor on which the dependence of the willingness to justify tax evasion has been tested is the willingness to fight for one's country. In this case, respondents answered the question of whether they would be willing to fight for their country in the event of war or not. This factor was chosen because the willingness to fight for one's country is associated with a certain loyalty to the government and patriotism, which is also linked to tax compliance. To the best of our knowledge, this factorhas not yet been directly examined in the previous analyzes of tax evasion.

In all three countries, it has been shown that individuals who would be willing to fight for their country in the event of war a re also less likely to justify cheating on tax. The highest percentage of those who would be willing to fight for their country in the event of war was recorded in Poland, which corresponds to the fact that Poland is the country with the highest tax morale among the three observed countries. The fact that a certain loyalty to the state is related to tax compliance is also proved by the results of the research in Spain. Spain has both low tax morale and a very low loyalty to its country. Approximately $62 \%$ of respondents in Spain said they would not be willing to fight for their country in the event of war. The Czech Republic was dominated by the number of those who would be willing to defend their country, but the difference is not as striking as in the case of Poland.

\section{Proud Citizen}

The justification of tax evasion was further tested on the criterion of how proud individuals are to be a citizen of their country. This is a nother of the factors that, as far as we know, has not been studied before. In the case of the Czech Republic and Spain, the 
dependence between citizens' pride and their willingness to tolerate tax evasion has been proved. From the results, it can be said that the pride of citizens has a very significant effect on tax morale, so that with increasing pride, the willingness to justify tax evasion clearly decreases.

Although it was not possible to perform a statistical dependency test for Poland, some influence could be observed from the data. For example, in the group of individuals who are not at all proud to be Polish citizens, more than $25 \%$ always justify cheating on tax. Based on these results, it can be stated that the pride of citizens has a positive effect on tax morale in Poland as well.

\section{Respect for authority}

The last factor tested in this analysis is respect for authorities. In this question, the respondents assessed the change in the way of life, specifically they answered the question of whether they consider greater respect for the authorities to be a good change, a bad change or they do not care. Again, this is a new factor that has not yet been directly analyzed in the literature.

The statistical test succeeded in proving that the justification of tax evasion in the Czech Republic and Spain depends on the perception of respect for authorities. Individuals who see an increase in respect for the authorities as a good change show slightly higher tax morale than those who do not care or perceive the change negatively. In the case of Poland, however, this dependence has not been statistically proved.

\section{Conclusion}

From the demographic factors, the effect of gender on the willingness to justify tax evasion was the most obvious. Women were less tolerant of cheating on tax than men in the Czech Republic and Poland, however, this relationship was not confirmed in Spain. Overall, this confirms the results of the previous research. It has also been shown that tax morale tends to increase with age. The statistical test proved this relationship for the Czech Republic, for Poland this effect of age on tax morale could only be inferred from the chart. The dependence of tax morale on age was not confirmed for Spain at all.

A significant difference in the attitude to tax compliance was noted for taxpayers who belong to a religious group. Religious people in all the observed countries are considerably less tolerant of tax evasion than those who do not identify themselves with any religion. Statistically, it was proved for the Czech Republic and Spain, in Poland, there were not enough respondents who would approve cheating on tax to perform a valid statistical chi-square test, but the dependence of tax morale and religion was detectable from the data.

Education of respondents did not prove to be essential for the opinion on tax fraud. On the other hand, a clearly visible role in the willingness to justify cheating on tax plays low confidence in government and authorities in all three countries, which corresponds to the previous research.

Factors of patriotism, such as the willingness to fight for own country and the pride of being the citizen of the country, have a positive impact on tax morale in all three countries that were examined. The same (positive) influence on tax morale has the respect for 
authorities, aga in, this was observed for all three countries. We can conclude that patriotism and the respect for authorities have a positive effect on tax morale and tax compliance. Therefore, it is desirable for tax administration and tax policy makers to support these phenomena.

In an overall comparison of countries, we found that they differ in the influence of demographic factors, which in Spain did not show a connection with tax evasion, while in the Czech Republic and in the case of gender questions also in Poland, this connection was clearly demonstrated. On the contrary, when examining the attitudes of the respondents, especially on the issue of patriotism, the connection with tax evasion was proved in all three countries.

When evaluating the results of our analysis, it should be borne in mind that decisions not to pay taxes are sensitive for the individual respondents and they may give the answers they consider acceptable and not express their true views (Slemrod, 2007, Slemrod and Weber, 2012). Therefore, the a ssessment of the level of tax morale on the basis of a questionnaire survey may have limited informative value. The tax administration and the tax system of a particular country must also be taken into account, as the conditions for collecting taxes and tax legislation are significant for the economic decisions and tax compliance of taxpayers (Bortel, 2005).

Tax administrations cannot influence the demographic and social factors of taxpayers' decisions about tax evasion, but their knowledge can help to steer tax policy in the right direction. The a nalysis showed that higher tax morale and, subsequently, better tax collection, can be achieved by supporting the identification of citizens with their state and government. This could also increase the respect for authorities which is anotherimportant factor supporting the willingness to comply with tax legislation.

Funding: The paperwas prepared as one of the outputs of a research project of the Faculty of Finance and Accounting at the Prague University of Economics and Business „Economic and institutional a spects of public finance“ registered by the Internal Grant Agency of Prague University of Economics and Business under the registration number F1/7/2019 and it was also funded by the institutional support IP 100040 at the Faculty of Finance and Accounting at the Prague University of Economics and Business.

Disclosure statement: No potentialconflict of interest was reported by the authors.

\section{References}

AGHA, A., HAUGHTON, J. (1996): Designing VAT Systems: Some Efficiency Considerations. The Review of Economics and Statistics, 78, No. 2, pp. 303 - 308. DOI: $\underline{10.2307 / 2109932}$

ALLINGHAM, Michael G. and Agnar SANDMO. (1972). Income tax evasion: a theoretical analysis, Journal of Public Economics, 1, issue 3-4, p. 323-338.

ALM, J. (2012). Measuring, Explaining, and Controlling Tax Evasion: Lessons from Theory, Experiments, and Field Studies. International Tax and Public Finance, 19(1), 5477. DOI: $\underline{10.1007 / \mathrm{s} 10797-011-9171-2}$ 
ALM, J., SCHULZE, W.D., BOSE, C., YAN, J. (2019). Appeals to Social Norms and Taxpayer Compliance. Southern Economies Journal. DOI: 10.1002/soej.12374

BAZART, C., PICKHARDT, M. (2011). Fighting Income Tax Evasion with Positive Rewards. Public Finance Review, 39(1), 124-149. DOI: 10.1177/1091142110381639

BLOOMQUIST, K. (2011). Tax Compliance as an Evolutionary Coordination Game: An Agent-Based Approach. Public Finance Review, 39(1), 25-49. DOI: $\underline{10.1177 / 1091142110381640}$

BICCHIERI, C., XIAO, E. (2009). Do the right thing: but only if others do so. Journal of Behavioral Decision Making, 22(2), 191-208. DOI: 10.1002/bdm.621

BORTEL, L. (2005). Legal systems and economic performance. Review of Economic Perspectives. Vol. 5, No.1. http://nho.econ.muni.cz/rocnik-2005/12005

CASE \& IEB. Study and Reports on the VAT Gap in the EU-28 Member States: 2019 Final Report [online]. 2019. Available from: https://ec.europa.eu/taxation_customs/business/tax-cooperation-control/vat-gap_en

DALAMAGAS, B. (2011). A Dynamic Approach to Tax Evasion. Public Finance Review, 39(2), 309-326. DOI: 10.1177/1091142110386213

DAUDE, C., H. GUTIÉRREZ, MELGUIZO, Á., (2012), What Drives Tax Morale?, OECD Development Centre Working Papers, No. 315, OECD Publishing, Paris, DOI: $10.1787 / 5 \mathrm{k} 8 \mathrm{zk} 8 \mathrm{~m} 61 \mathrm{kzq}-\mathrm{en}$

DELl'ANNO, R. (2009). Tax Evasion, Tax Morale and Policy Maker's Effectiveness. Journal of Socio-Economics, 38(6), 988-997. DOI: 10.1016/j.socec.2009.06.005

DEVOS, K., 2014. Factors influencing individual taxpayer compliance behaviour. Dordbrecht: Springer. DOI: 10.1007/978-94-007-7476-6

European Values Study: About EVS [online]. Accessed 2020-04-20 from: https://europeanvaluesstudy.eu/about-evs/

EVS (2019): European Values Study 2017: Integrated Data set (EVS 2017). GESIS Data Archive, Cologne. ZA7500 Data file Version 2.0.0, DOI: 10.4232/1.13314

FILER, R. K., HANOUSEK, J., LICHARD, T., TOROSYAN, K., (2019). "Flattening" the Tax Evasion. The Economics of Transition and Institutional Change [online]. Vol. 27, No. 1, s. 223-224. Accessed 31. 7. 2020 from: <https://econpapers.repec.org/article/blaetrans/v_3a27_3ay_3a2019_3ai_3a1_3ap_3a223-246.htm>.

DOI: 10.1111/ecot.12189.

GAVIRIA, A. (2008). Social Mobility and Preferences for Redistribution in Latin America, Economía, vol. 8, no. 1, pp. 55-96.

HANOUSEK, Jan and PALDA, Filip, (2002), Quality of Government Services and the Civic Duty to Pay Taxes in the Czech and Slovak Republics, and other Transition Countries, Public Economics, University Library of Munich, Germany, https://EconPapers.repec.org/RePEc:wpa:wuwppe:0209007 
HOFMANN, E., HOELZL E., and KIRCHLER. E, (2008). "Preconditions of voluntary tax compliance: Knowledge and evaluation of taxation, norms, fairness, and motivation to cooperate". Journal of Psychology 216 (4): 209-17

HORODNIC, I. A., 2018. Tax Morale and Institutional Theory: A Systematic Review. International Journal of Sociology and Social Policy. Vol. 38, č. 9/10, s. 868-886. DOI: $\underline{10.1108 / I J S S P-03-2018-0039}$

HUG, S. and SPORRI, F. (2011), "Referendums, Trust, and Tax Evasion”, European Journal of Political Economy, 27 (1): 120-131. DOI: 10.1016/j.ejpoleco.2010.06.005

CHRISTIE, E. - HOLZNER, M. (2006): What Explains Tax Evasion? An Empirical Assessment Based on European Data. [WIIW, Working Paper 40.] Available from: <http://www.wiiw.ac.at/pdf/wp40.pdf>.

CHUNG, J., TRIVEDI, V.U. (2003) The Effect of Friendly Persuasion and Gender on Tax Comliance Behavior.Journal of Business Ethics, 47,133-145. DOI: 10.1023/A: 1026004716676

JOSHI, A. (2019). Tax and Gender in Developing Countries: What are the Issues? InternationalCentre for Tax and Development at the Institute of Development Studies. Summary Brief Number 6. Brighton. Retrieved from: https://opendocs.ids.ac.uk/opendocs/bitstream/handle/20.500.12413/13066/ICTD_SumBrief\%236_Onli-

neNew2.pdf? sequence $=1 \&$ isAllowed $=y$

KIRCHLER, E., (2007). The economic psychology of tax behaviour. Cambridge. Cambridge University Press.

Kirchler et al. (2019). Mentalaccounting of income tax and value added tax among self employed business owners. Journal of Economic Psychology. DOI:

10.1016/J.JOEP.2018.12.007

KONRAD, K.A.QARI, S. (2011). The last refuge of a scoundrel? Patriotism and tax compliance. Economica. DOI: 10.1111/j.1468-0335.2011.00900.x

LEDYARD, J. O. (1995). Public Goods: A Survey of Experimental Research. In J. H. Kagel \& A. E. Roth (Eds.), The handbook of experimental economics (pp. 111-194). Princeton: Retrieved from http://search.ebscohost.com.zdroje.vse.cz:2048/login.aspx?direct $=$ true $\& \mathrm{db}=$ eoh $\& A N=0453736 \&$ lang $=$ cs\&site $=$ ehost-live

LEROY, M., (2008). Tax Sociology, Sociopolitical Issues for a Dialogue with Economists. Socio Logos. 3. 1-28. Retrieved from: http://journals.openedition.org/socio$\operatorname{logos} / 2073$

LEROY, M., (2011). Taxation, The State And Society: The Fiscal Sociology Of Interventionist Democracy. P.I.E-Peter Lang S.A. Isbn-13: 978-9052016979MUEHLBACHER, S., KIRCHLER, E., \& SCHWARZENBERGER, H. (2011). Voluntary versus Enforced Tax Compliance: Empirical Evidence for the "Slippery Slope" Framework. European Journal of Law and Economics, 32(1), 89-97. https://doiorg.zdroje.vse.cz/https://link.springer.com/journal/volumesAndIssues/10657 
OECD (2002). Measuring the Non-Observed Economy: A Handbook. Paris: OECD Publications. ISBN 92-64-19745-1.

OECD. (2010). Understanding and Influencing Taxpayers' Compliance Behaviour, France, Paris: OECD Forum on Tax Administration.

OECD (2019), Tax Morale: What Drives People and Businesses to Pay Tax?, OECD Publishing, Paris, https://doi.org/10.1787/f3d8ea10-en.

SLEMROD, J. (2007). Cheating Ourselves: The Economics of Tax Evasion. The Journal of Economic Perspectives, 21(1), 25-48. Retrieved September 12, 2021, DOI: 10.1257/jep.21.1.25

SLEMROD, J., Weber, C., (2012). Evidence of the Invisible: Toward a Credibility Revolution in the Empirical Analysis of Tax Evasion and the Informal Economy. International Tax and Public Finance, 19(1), 25-53. https://doiorg.zdroje.vse.cz/https://link.springer.com/journa1/volum esAndIssues/10797

TORGLER, B., (2007). Tax Compliance and Tax Morale.Edward Elgar Publishing. DOI: $10.4337 / 9781847207203$.

TORGLER, B., (2012). Tax morale, Eastern Europe and European enlargement. Communist and Post-Communist Studies 1 June 2012; 45 (1-2): 11-25. DOI: DOI: 10.1016/j.postcomstud.2012.02.005

WALSH, K., (2012). Understanding Taxpayer Behaviour - New Opportunities for Tax Administration. Economic and Social Review . 43. 451-475.

YITZHAKI, S. (1974). A Note on Income Tax Evasion: A Theoretical Analysis. Journal of Public Economics, 3(2), 201-202. DOI: 10.1016/0047-2727(74)90037-1

ZÍDKOVÁ, H.; TEPPEROVÁ, J., HELMAN, K. (2018). EVS data-based analysis of tax evasion: Descriptive vs. regression modelling. Society and economy in Central and Eastern Europe: journal of the Corvinus University of Budapest. 2018. Vol. 40, č. 1, s. 89-103. ISSN 1588-9726. DOI: 10.1556/204.2018.40.1.6 


\section{Appendix}

Gender $-\chi^{2} 0,95(4)=9,49$

Table 5. Gender - The Czech Republic

\begin{tabular}{|r|r|r|r|r|r|r|}
\hline Gender & Never & Rather not & Do not know & Rather yes & Always & Total \\
\hline Male & 417 & 166 & 85 & 13 & 15 & 696 \\
\hline Female & 739 & 181 & 126 & 13 & 13 & 1072 \\
\hline Total & 1156 & 347 & 211 & 26 & 28 & 1768 \\
\hline
\end{tabular}

Source: Author's calculation based on data from the European Values Study

$\mathrm{G}=20,89$

Table 6. Gender - Poland

\begin{tabular}{|r|r|r|r|r|r|r|}
\hline Gender & Never & Rather not & Do not know & Rather yes & Always & Total \\
\hline Male & 461 & 113 & 24 & 8 & 9 & 615 \\
\hline Female & 605 & 90 & 16 & 6 & 2 & 719 \\
\hline Total & 1066 & 203 & 40 & 14 & 11 & 1334 \\
\hline
\end{tabular}

Source: Author's calculation based on data from the European Values Study

$\mathrm{G}=20,41$

Table 7. Gender - Spain

\begin{tabular}{|r|r|r|r|r|r|r|}
\hline Gender & Never & Rather not & Do not know & Rather yes & Always & Total \\
\hline Male & 267 & 135 & 42 & 61 & 21 & 526 \\
\hline Female & 369 & 146 & 44 & 64 & 26 & 649 \\
\hline Total & 636 & 281 & 86 & 125 & 47 & 1175 \\
\hline
\end{tabular}

Source: Author's calculation based on data from the European Values Study

$\mathrm{G}=4,61$

Age $-\chi^{2} 0,95(20)=31,41$ 
Table 8. Age - The Czech Republic

\begin{tabular}{|r|r|r|r|r|r|r|}
\hline Age & Never & Rather not & Do not know & Rather yes & Always & Total \\
\hline $\mathbf{1 5 - 2 4}$ & 55 & 27 & 12 & 5 & 4 & 103 \\
\hline $\mathbf{2 5 - 3 4}$ & 128 & 78 & 18 & 13 & 6 & $\mathbf{2 4 3}$ \\
\hline $\mathbf{3 5 - 4 4}$ & 199 & 80 & 28 & 12 & 3 & $\mathbf{3 2 2}$ \\
\hline $\mathbf{4 5 - 5 4}$ & 157 & 66 & 22 & 11 & 7 & $\mathbf{2 6 3}$ \\
\hline $\mathbf{5 5 - 6 4}$ & 197 & 61 & 16 & 7 & 3 & $\mathbf{2 8 4}$ \\
\hline $\mathbf{6 5 +}$ & 386 & 85 & 18 & 4 & 2 & $\mathbf{4 9 5}$ \\
\hline Total & 1122 & 397 & 114 & $\mathbf{5 2}$ & $\mathbf{2 5}$ & $\mathbf{1 7 1 0}$ \\
\hline
\end{tabular}

Source: Author's calculation based on data from the European Values Study

$\mathrm{G}=83,38$

Figure 1. Age - Poland

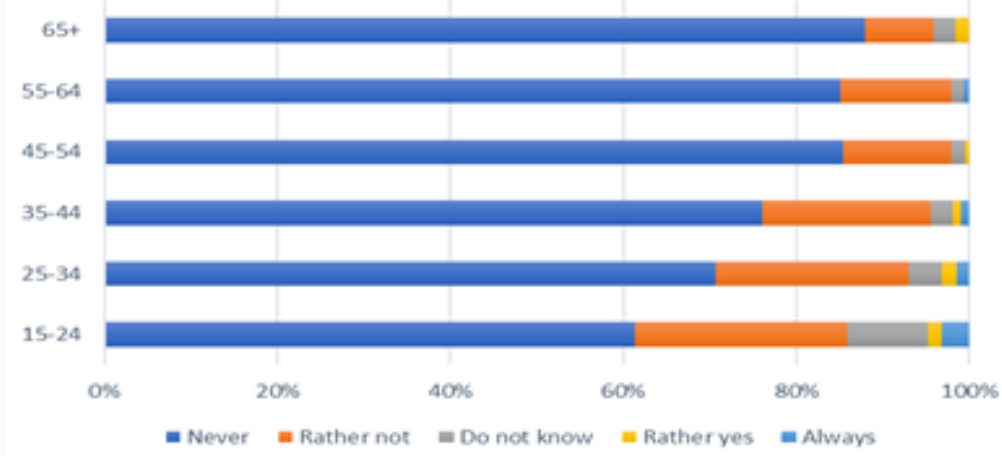

Source: Author's modification based on data from the European Values Study

Table 9. Age - Spain

\begin{tabular}{|r|r|r|r|r|r|r|}
\hline Age & Never & Rather not & Do not know & Rather yes & Always & Total \\
\hline $\mathbf{1 5 - 2 4}$ & 45 & 21 & 12 & 7 & 4 & $\mathbf{8 9}$ \\
\hline $\mathbf{2 5 - 3 4}$ & 91 & 46 & 6 & 15 & 3 & $\mathbf{1 6 1}$ \\
\hline $\mathbf{3 5 - 4 4}$ & 121 & 55 & 13 & 16 & 13 & $\mathbf{2 1 8}$ \\
\hline $\mathbf{4 5 - 5 4}$ & 117 & 67 & 17 & 33 & 12 & $\mathbf{2 4 6}$ \\
\hline $\mathbf{5 5 - 6 4}$ & 103 & 35 & 17 & 18 & 6 & $\mathbf{1 7 9}$ \\
\hline $\mathbf{6 5 +}$ & 159 & 57 & 21 & 36 & 9 & $\mathbf{2 8 2}$ \\
\hline Total & $\mathbf{6 3 6}$ & $\mathbf{2 8 1}$ & $\mathbf{8 6}$ & $\mathbf{1 2 5}$ & $\mathbf{4 7}$ & $\mathbf{1 1 7 5}$ \\
\hline
\end{tabular}

Source: Author's calculation based on data from the European Values Study

$\mathrm{G}=29,38$ 
Educational Attainment $-\chi^{2} 0,95(8)=15,51$

Table 10. Educational Attainment - The Czech Republic

\begin{tabular}{|r|r|r|r|r|r|r|}
\hline Educational Attainment & Never & Rather not & Do not know & Rather yes & Always & Total \\
\hline Primary & 119 & 37 & 9 & 4 & 2 & 171 \\
\hline Secondary & 815 & 286 & 84 & 36 & 21 & 1242 \\
\hline Higher & 210 & 88 & 25 & 14 & 4 & 341 \\
\hline Total & 1144 & 411 & 118 & 54 & 27 & 1754 \\
\hline
\end{tabular}

Source: Author's calculation based on data from the European Values Study

$\mathrm{G}=5,33$

Table 11. Educational Attainment - Poland

\begin{tabular}{|r|r|r|r|r|r|r|}
\hline Educational Attainment & Never & Rather not & Do not know & Rather yes & Always & Total \\
\hline Primary & 365 & 63 & 10 & 4 & 5 & 447 \\
\hline High & 410 & 69 & 18 & 7 & 5 & 509 \\
\hline Higher & 290 & 70 & 12 & 3 & 2 & 377 \\
\hline Total & 1065 & 202 & 40 & 14 & 12 & 1333 \\
\hline
\end{tabular}

Source: Author's calculation based on data from the European Values Study

$\mathrm{G}=7,80$

Table 12. Educational Attainment - Spain

\begin{tabular}{|r|r|r|r|r|r|r|}
\hline Educational Attainment & Never & Rather not & Do not know & Rather yes & Always & Total \\
\hline Primary & 352 & 137 & 43 & 69 & 25 & 626 \\
\hline High & 135 & 75 & 28 & 33 & 10 & $\mathbf{2 8 1}$ \\
\hline Higher & 147 & 69 & 15 & 21 & 12 & $\mathbf{2 6 4}$ \\
\hline Total & $\mathbf{6 3 4}$ & $\mathbf{2 8 1}$ & $\mathbf{8 6}$ & $\mathbf{1 2 3}$ & $\mathbf{4 7}$ & $\mathbf{1 1 7 1}$ \\
\hline
\end{tabular}

Source: Author's calculation based on data from the European Values Study

$\mathrm{G}=11,42$ 
Religion $-\chi^{2} 0,95(4)=9,49$

Table 13. Religion - The Czech Republic

\begin{tabular}{|r|r|r|r|r|r|r|}
\hline Religion & Never & Rather not & Do not know & Rather yes & Always & Total \\
\hline Yes & 325 & 97 & 18 & 12 & 7 & 459 \\
\hline No & 819 & 307 & 98 & 41 & 21 & 1286 \\
\hline Total & 1144 & 404 & 116 & 53 & 28 & 1745 \\
\hline
\end{tabular}

Source: Author's calculation based on data from the European Values Study

$\mathrm{G}=11,07$

Figure 2. Religion - Poland

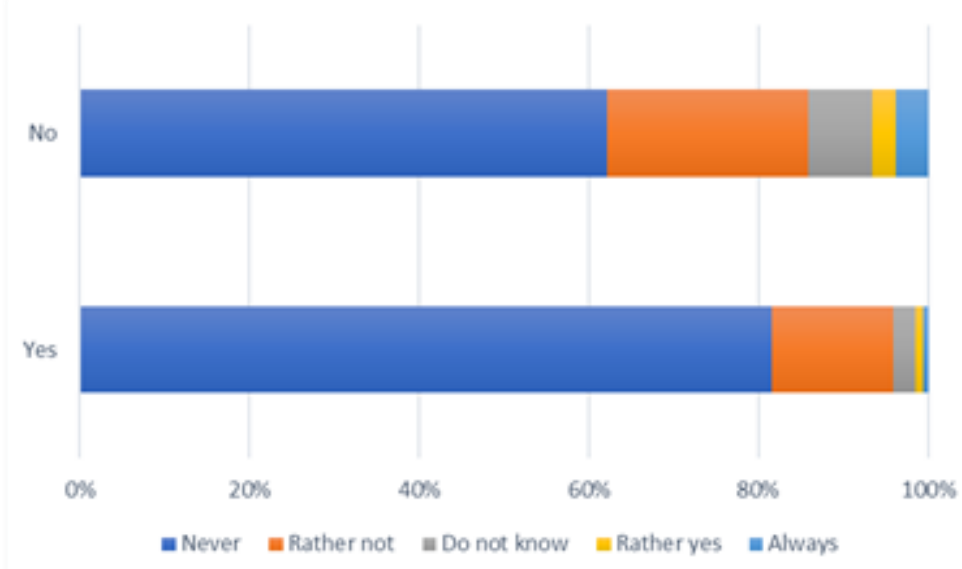

Source: Author's modification based on data from the European Values Study

Table 14. Religion - Spain

\begin{tabular}{|r|r|r|r|r|r|r|}
\hline Religion & Never & Rather not & Do not know & Rather yes & Always & Total \\
\hline Yes & 428 & 162 & 46 & 86 & 30 & 752 \\
\hline No & 207 & 115 & 40 & 38 & 17 & 417 \\
\hline Total & 635 & 277 & 86 & 124 & 47 & 1169 \\
\hline
\end{tabular}

Source: Author's calculation based on data from the European Values Study

$\mathrm{G}=12,51$ 
Confidence in Government and Authorities - $\chi^{2} 0,95(16)=26,30$

Table 15. Confidence in Government and Authorities - The Czech Republic

\begin{tabular}{|r|r|r|r|r|r|r|}
\hline $\begin{array}{r}\text { Confidence in Govern- } \\
\text { ment and Authorities }\end{array}$ & Never & Rather not & Do not know & Rather yes & Always & Total \\
\hline Very high & 54 & 13 & 7 & 1 & 1 & $\mathbf{7 6}$ \\
\hline High & 349 & 101 & 26 & 19 & 9 & $\mathbf{5 0 4}$ \\
\hline Not too high & 563 & 209 & 56 & 16 & 5 & $\mathbf{8 4 9}$ \\
\hline None at all & 149 & 72 & 28 & 16 & 10 & $\mathbf{2 7 5}$ \\
\hline Total & 1115 & $\mathbf{3 9 5}$ & $\mathbf{1 1 7}$ & $\mathbf{5 2}$ & $\mathbf{2 5}$ & $\mathbf{1 7 0 4}$ \\
\hline
\end{tabular}

Source: Author's calculation based on data from the European Values Study

$\mathrm{G}=45,26$

Figure 3. Confidence in Government and Authorities - Poland

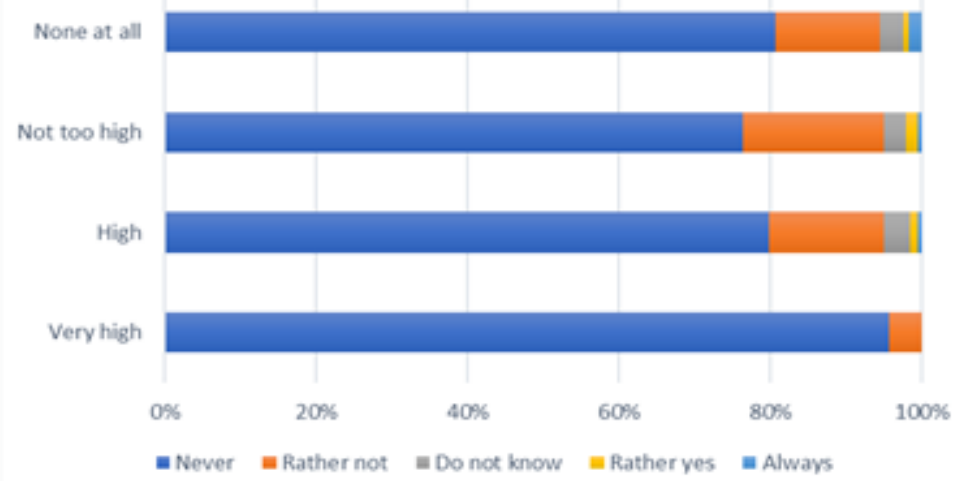

Source: Author's modification based on data from the European Values Study

Table 16. Confidence in Government and Authorities - Spain

\begin{tabular}{|r|r|r|r|r|r|r|}
\hline $\begin{array}{r}\text { Confidence in Govern- } \\
\text { ment and Authorities }\end{array}$ & Never & Rather not & Do not know & Rather yes & Always & Total \\
\hline Very high & 79 & 22 & 6 & 13 & 1 & 121 \\
\hline High & 220 & 101 & 34 & 61 & 13 & 429 \\
\hline Not too high & 222 & 118 & 34 & 41 & 22 & 437 \\
\hline None at all & 100 & 36 & 10 & 6 & 11 & 163 \\
\hline Total & $\mathbf{6 2 1}$ & $\mathbf{2 7 7}$ & $\mathbf{8 4}$ & $\mathbf{1 2 1}$ & $\mathbf{4 7}$ & 1150 \\
\hline
\end{tabular}

Source: Author's calculation based on data from the European Values Study

$\mathrm{G}=32,57$ 
Confidence in Other People in Society - $\chi^{2} 0,95(4)=9,49$

Table 17. Confidence in Other People in Society - The Czech Republic

\begin{tabular}{|r|r|r|r|r|r|r|}
\hline $\begin{array}{r}\text { Confidence in Other Peo- } \\
\text { ple in Society }\end{array}$ & Never & Rather not & Do not know & Rather yes & Always & Total \\
\hline $\begin{array}{r}\text { It is possible to trust peo- } \\
\text { ple }\end{array}$ & 261 & 91 & 23 & 9 & 1 & 385 \\
\hline $\begin{array}{r}\text { One must be very careful } \\
\text { in dealing with other peo- } \\
\text { ple }\end{array}$ & 846 & 290 & 91 & 41 & 27 & 1295 \\
\hline Total & 1107 & 381 & 114 & 50 & 28 & 1680 \\
\hline
\end{tabular}

Source: Author's calculation based on data from the European Values Study

$\mathrm{G}=7,58$

Table 18. Confidence in Other People in Society - Poland

\begin{tabular}{|c|c|c|c|c|c|c|}
\hline $\begin{array}{r}\text { Confidence in Other Peo- } \\
\text { ple in Society }\end{array}$ & Never & Rather not & Do not know & Rather yes & Always & Total \\
\hline $\begin{array}{r}\text { It is possible to trust peo- } \\
\text { ple }\end{array}$ & 250 & 64 & 12 & 4 & 3 & 333 \\
\hline $\begin{array}{r}\text { One must be very careful } \\
\text { in dealing with other peo- } \\
\text { ple }\end{array}$ & 787 & 134 & 27 & 10 & 7 & 965 \\
\hline Total & 1037 & 198 & 39 & 14 & 10 & 1298 \\
\hline
\end{tabular}

Source: Author's calculation based on data from the European Values Study

$\mathrm{G}=6,61$

Table 19. Confidence in Other People in Society - Spain

\begin{tabular}{|r|r|r|r|r|r|r|}
\hline $\begin{array}{r}\text { Confidence in Other Peo- } \\
\text { ple in Society }\end{array}$ & Never & Rather not & Do not know & Rather yes & Always & Total \\
\hline $\begin{array}{r}\text { It is possible to trust peo- } \\
\text { ple }\end{array}$ & 266 & 109 & 31 & 56 & 21 & 483 \\
\hline $\begin{array}{r}\text { One must be very careful } \\
\text { in dealing with other peo- } \\
\text { ple }\end{array}$ & 362 & 170 & 53 & 69 & 24 & 678 \\
\hline Total & 628 & 279 & 84 & 125 & 45 & 1161 \\
\hline
\end{tabular}

Source: Author's calculation based on data from the European Values Study

$\mathrm{G}=2,65$ 
Willing to Fight for Own Country - $\chi^{2} 0,95(4)=9,49$

Table 20. Willing to Fight for Own Country - The Czech Republic

\begin{tabular}{|r|r|r|r|r|r|r|}
\hline $\begin{array}{r}\text { Willing to Fight for Own } \\
\text { Country }\end{array}$ & Never & Rather not & Do not know & Rather yes & Always & Total \\
\hline Yes & 564 & 183 & 42 & 24 & 10 & $\mathbf{8 2 3}$ \\
\hline No & 341 & 148 & 54 & 19 & 16 & $\mathbf{5 7 8}$ \\
\hline Total & $\mathbf{9 0 5}$ & 331 & 96 & 43 & $\mathbf{2 6}$ & $\mathbf{1 4 0 1}$ \\
\hline
\end{tabular}

Source: Author's calculation based on data from the European Values Study

$\mathrm{G}=19,88$

Table 21. Willing to Fight for Own Country - Poland

\begin{tabular}{|r|r|r|r|r|r|r|}
\hline $\begin{array}{r}\text { Willing to Fight for Own } \\
\text { Country }\end{array}$ & Never & Rather not & Do not know & Rather yes & Always & Total \\
\hline Yes & 806 & 138 & 26 & 8 & 5 & 983 \\
\hline No & 185 & 49 & 11 & 6 & 3 & $\mathbf{2 5 4}$ \\
\hline Total & 991 & 187 & 37 & 14 & $\mathbf{8}$ & $\mathbf{1 2 3 7}$ \\
\hline
\end{tabular}

Source: Author's calculation based on data from the European Values Study

$\mathrm{G}=13,40$

Table 22. Willing to Fight for Own Country - Spain

\begin{tabular}{|r|r|r|r|r|r|r|}
\hline $\begin{array}{r}\text { Willing to Fight for Own } \\
\text { Country }\end{array}$ & Never & Rather not & Do not know & Rather yes & Always & Total \\
\hline Yes & 241 & 91 & 22 & 24 & 18 & 396 \\
\hline No & 318 & 159 & 53 & 95 & 27 & 652 \\
\hline Total & 559 & 250 & 75 & 119 & 45 & 1048 \\
\hline
\end{tabular}

Source: Author's calculation based on data from the European Values Study

$\mathrm{G}=25,04$ 
Proud Citizen $-\chi^{2} 0,95(16)=26,30$

Table 23. Proud Citizen - The Czech Republic

\begin{tabular}{|r|r|r|r|r|r|r|}
\hline Proud Citizen & Never & Rather not & Do not know & Rather yes & Always & Total \\
\hline Very proud & 419 & 102 & 26 & 11 & 7 & $\mathbf{5 6 5}$ \\
\hline Quite proud & 521 & 180 & 50 & 21 & 6 & $\mathbf{7 7 8}$ \\
\hline Not very proud & 107 & 74 & 21 & 7 & 5 & $\mathbf{2 1 4}$ \\
\hline Not at all proud & 11 & 6 & 4 & 8 & 6 & $\mathbf{3 5}$ \\
\hline Total & 1058 & $\mathbf{3 6 2}$ & 101 & $\mathbf{4 7}$ & $\mathbf{2 4}$ & $\mathbf{1 5 9 2}$ \\
\hline
\end{tabular}

Source: Author's calculation based on data from the European Values Study

$\mathrm{G}=157,59$

Figure 4. Proud Citizen - Poland

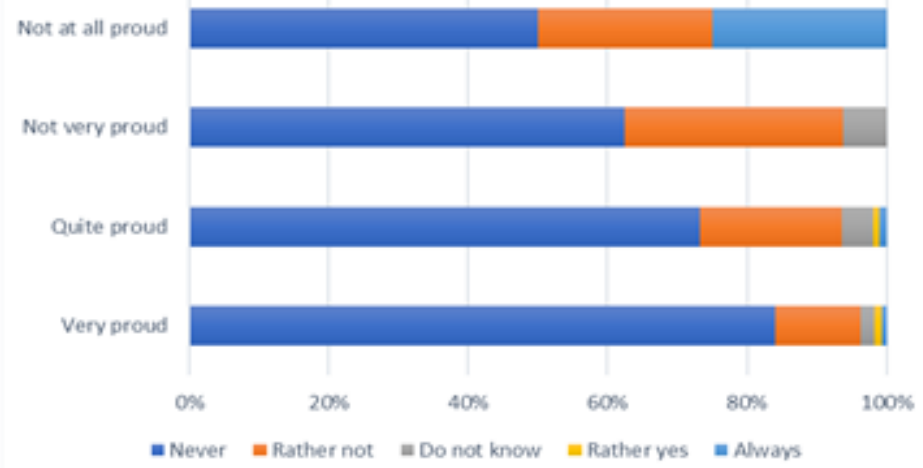

Source: Author's modification based on data from the European Values Study

Table 24. Proud Citizen - Spain

\begin{tabular}{|r|r|r|r|r|r|r|}
\hline Proud Citizen & Never & Rather not & Do not know & Rather yes & Always & Total \\
\hline Very proud & 276 & 87 & 16 & 59 & 27 & $\mathbf{4 6 5}$ \\
\hline Quite proud & 250 & 116 & 52 & 41 & 13 & $\mathbf{4 7 2}$ \\
\hline Not very proud & 49 & 40 & 8 & 9 & 0 & 106 \\
\hline Not at all proud & 24 & 18 & 5 & 6 & 3 & $\mathbf{5 6}$ \\
\hline Total & 599 & $\mathbf{2 6 1}$ & $\mathbf{8 1}$ & 115 & $\mathbf{4 3}$ & 1099 \\
\hline
\end{tabular}

Source: Author's calculation based on data from the European Values Study

$\mathrm{G}=53,24$ 
Respect for Authority $-\chi^{2} 0,95(8)=15,51$

Table 25. Respect for Authority - The Czech Republic

\begin{tabular}{|r|r|r|r|r|r|r|}
\hline Respect for Authority & Never & Rather not & Do not know & Rather yes & Always & Total \\
\hline Good & 528 & 167 & 52 & 23 & 9 & $\mathbf{7 7 9}$ \\
\hline Bad & 214 & 88 & 17 & 7 & 7 & 333 \\
\hline Do not mind & 223 & 98 & 35 & 21 & 6 & $\mathbf{3 8 3}$ \\
\hline Total & 965 & 353 & 104 & 51 & $\mathbf{2 2}$ & 1495 \\
\hline
\end{tabular}

Source: Author's calculation based on data from the European Values Study

$\mathrm{G}=19,72$

Figure 5. Respect for Authority - Poland

Do not mind

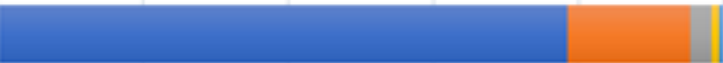

Bad

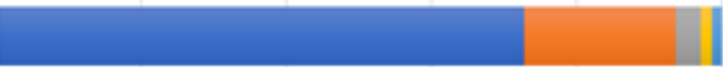

Good
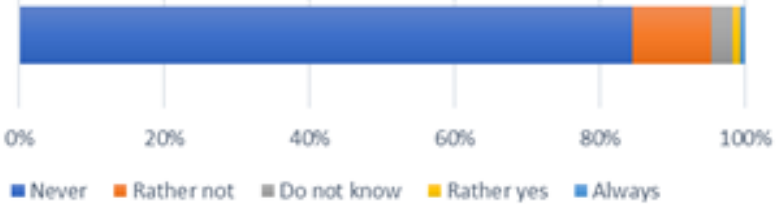

Source: Author's modification based on data from the European Values Study

Table 26. Respect for Authority - Spain

\begin{tabular}{|r|r|r|r|r|r|r|}
\hline Respect for Authority & Never & Rather not & Do not know & Rather yes & Always & Total \\
\hline Good & 425 & 181 & 41 & 86 & 36 & 769 \\
\hline Bad & 88 & 31 & 20 & 20 & 5 & 164 \\
\hline Do not mind & 87 & 56 & 21 & 15 & 4 & 183 \\
\hline Total & 600 & 268 & 82 & 121 & 45 & 1116 \\
\hline
\end{tabular}

Source: Author's calculation based on data from the European Values Study

$\mathrm{G}=24,83$ 